\title{
Comparison of Nerve Fiber Density between Patients with Uterine Leiomyoma with and without Pain: a Prospective Clinical Study
}

\author{
Vergleich der Nervenfaserdichte bei Patientinnen \\ mit Leiomyomen des Uterus mit und ohne Schmerzbefund: \\ eine prospektive klinische Studie
}

\section{(ㄷ) (i) (오 $\ominus$}

Authors

Burak Giray ${ }^{1}$, Esra Esim-Buyukbayrak ${ }^{2}$, Sevinc Hallac-Keser ${ }^{3}$, Ayse Yasemin Karageyim-Karsidag ${ }^{4}$, Aysegul Turkgeldi $^{5}$

Affiliations

1 Department of Gynecologic Oncology, Zeynep Kamil Women's and Children's Disease Training and Research Hospital, Istanbul, Turkey

2 Department of Perinatology, Marmara University Pendik Training and Research Hospital, Istanbul, Turkey

3 Department of Pathology, Dr. Lutfi Kirdar Kartal Training and Research Hospital, Istanbul, Turkey

4 School of Health, Kirklareli University, Kirklareli, Turkey

5 Department of Gynecology and Obstetrics, Dr. Lutfi Kirdar Kartal Training and Research Hospital, Istanbul, Turkey

Key words

nerve fibers, neurofilament, pelvic pain, protein gene product 9.5, uterine leiomyoma

\section{Schlüsselwörter}

Nervenfasern, Neurofilament, Beckenschmerzen, Protein-Genprodukt 9.5, Leiomyom des Uterus

$\begin{array}{lr}\text { received } & 28.1 .2018 \\ \text { revised } & 13.3 .2018 \\ \text { accepted } & 13.3 .2018\end{array}$

Bibliography

DOI https://doi.org/10.1055/a-0591-1751

Geburtsh Frauenheilk 2018; 78: 407-411 @ Georg Thieme

Verlag KG Stuttgart · New York | ISSN 0016-5751

\section{Correspondence}

Burak Giray, MD

Department of Gynecologic Oncology, Zeynep Kamil

Women's and Children's Disease Training and Research

Hospital, Opr. Dr. Burhanettin Ustunel cd. No: 10

Uskudar, Istanbul, Turkey

burakgiray@gmail.com

\section{ABSTRACT}

Introduction We aimed to compare the presence and the amount of nerve fibers in endometrial, myometrial and leiomyoma tissues using protein gene product 9.5 (PGP 9.5) and neurofilament (NF) immunohistochemical staining in uterine leiomyoma patients with and without pain complaint.

Methods Patients undergoing hysterectomy for uterine leiomyoma were prospectively enrolled in the study. Twenty-five uterine leiomyoma patients without pelvic pain complaint (visual analog scale (VAS) < 5) were assigned to Group 1; 23 uterine leiomyoma patients with pelvic pain complaint (VAS $\geq 5$ ) were assigned to Group 2. Endometrial, myometrial and leiomyoma tissues obtained from hysterectomy specimens were stained immunohistochemically using PGP 9.5 and NF dyes. The presence and density of nerve fibers were compared between the two groups.

Results None of the endometrial samples in either groups stained with PGP 9.5 and NF dyes. There was no statistically significant difference in the number of nerve fibers in myometrial and leiomyoma tissues between the two groups with either of the stains (PGP 9.5: $p=0.39$ and $p=0.29 ; \mathrm{NF}: \mathrm{p}=0.83$ and $p=0.65$, respectively). There was agreement between PGP 9.5 and NF immunohistochemical staining for nerve fiber detection in myometrial and leiomyoma tissues $(p<0.05 /$ $\mathrm{K}=0.622$ and $\mathrm{p}<0.05 / \mathrm{K}=0.388$, respectively).

Conclusion This study demonstrates that the quantity and density of nerve fibers in myometrial and leiomyoma tissue in patients with pain were similar to that in patients without pain.

\section{ZUSAMMENFASSUNG}

Einleitung Ziel dieser Studie war es, die Nervenfaserdichte in Gewebsproben, die dem Endometrium, dem Myometrium und den uterinen Leiomyomen entnommen wurden, zu vergleichen. Gewebsproben von Patientinnen mit Leiomyomen des Uterus mit und ohne Schmerzen wurden einer Immunfärbung mit Protein-Genprodukt 9.5 (PGP 9.5) und Neurofilament-(NF-)Antikörper unterzogen. 
Methoden Patientinnen, die sich einer Hysterektomie wegen Leiomyom des Uterus unterzogen, wurden prospektiv in die Studie aufgenommen. Fünfundzwanzig Patientinnen mit Leiomyom des Uterus ohne nennenswerte Schmerzen (visuelle Analogskala [VAS] <5) wurden in Gruppe 1 eingeteilt; 23 Patientinnen mit Leiomyom des Uterus und Schmerzen des kleinen Beckens (VAS $\geq 5$ ) wurden in Gruppe 2 eingeteilt. Die nach der Hysterektomie entnommenen Gewebsproben wurden einer immunhistochemischen Färbung mit PGP-9.5- bzw. NF-Antikörper unterzogen. Das Vorhandensein und die Anzahl vorhandener Nervenfasern wurden zwischen den beiden Gruppen (mit und ohne Schmerzen) verglichen.

Ergebnisse In beiden Gruppen ließen sich keine der endometrialen Gewebsproben mit PGP 9.5 oder NF einfärben. Zwi- schen den beiden Gruppen gab keine statistisch signifikanten Unterschiede in der Anzahl der mit PGP bzw. NF angefärbten Nervenfasern im Myometrium- bzw. Leiomyomgewebe (PGP 9.5: $p=0,39$ resp. $p=0,29 ; N F: p=0,83$ resp. $p=0,65$ ). Die immunhistologische Färbung mit PGP 9.5 zum Nachweis von Nervenfasern im Myometrium und Leiomyomgewebe stimmte im Wesentlichen mit den Befunden der NF-Färbung überein $(\mathrm{p}<0,05 / \mathrm{k}=0,622$ bzw. $\mathrm{p}<0,05 / \mathrm{k}=0,388)$.

Schlussfolgerung Diese Studie zeigt, dass es keine wesentlichen Unterschiede in der Quantität und Dichte der Nervenfasern im Myometrium und im Leiomyomgewebe gibt zwischen Patientinnen mit und Patientinnen ohne Schmerzen.

\section{Introduction}

Uterine leiomyomas are benign monoclonal tumors that originate from the smooth muscle of the uterus. Although $70 \%$ of uterine leiomyomas are asymptomatic, they can cause dysmenorrhea, menorrhagia, infertility, abortion, pelvic pressure and pain. Symptoms depend on the location and size of the uterine leiomyomas, although not in all cases [1].

Pelvic pain is a relatively common and important clinical symptom. Clinical studies have reported pelvic pain complaints in about $34 \%$ of patients with uterine leiomyoma [2]. The most commonly used scale for evaluating subjective pain is the "visual analog scale (VAS)". Patients rate the pain by giving it a score between 0 and 10 (i.e., from none to severe) [3]. We used this scale in the present study.

Endometriosis and uterine leiomyomas are common causes of pelvic pain. Increased nerve fibers in the endometrium have been detected in a majority of patients with endometriosis in some studies $[4,5]$. Because adenomyosis and uterine leiomyomas are believed to be controlled by the same steroid hormones as endometriosis, it was suggested that increased nerve fibers may be involved in the mechanism of pain generation in women with uterine leiomyomas. So far, only two studies have investigated the density of nerve fibers in the endometrium and myometrium of patients with endometriosis, adenomyosis and uterine leiomyomas with pain $[6,7]$. These studies retrospectively evaluated nerve fibers in the endometrium and myometrium, but not in leiomyoma tissue, and found increased nerve fibers in patients reporting pain.

Protein Gene Product 9.5 (PGP 9.5) is a specific marker for both myelinated and unmyelinated nerve fibers and neurofilament (NF) is a specific marker for unmyelinated nerve fibers [8]. We used these dyes as biological neuronal markers to detect nerve fibers in tissue, as was also done in the majority of studies in the literature.

A better understanding of the physiopathology of pain and its relationship to nerve fibers in uterine leiomyomas could contribute to better therapeutic management. For this reason, we aimed to prospectively compare the presence and density of nerve fibers in patients with or without pain.

\section{Methods}

\section{Participants and study design}

Premenopausal women between the ages of 40-50 undergoing hysterectomy for uterine leiomyoma were recruited prospectively into the study. The indications for hysterectomy included enlarged uterus, chronic pelvic pain, pelvic pressure symptoms, intractable menorrhagia or dysmenorrhea. The exclusion criteria were psychiatric or neurological disorders, disease that can alter the perception of pain (diabetes mellitus, etc.), hormone treatment for at least 6 months prior to surgery, and the presence of other gynecological diseases (adnexal masses, endometrioma, endometriosis, pelvic congestion syndrome, etc.). The study was approved by the Dr. Lutfi Kirdar Kartal Training and Research Hospital Ethical Committee (approval number: 89513307/1009/351). Oral and written informed consent was obtained from all patients scheduled for hysterectomy because of uterine leiomyoma who agreed to participate in the study.

The sample size was calculated on the basis of a previous study conducted by Zhang et al., which had reported a $69 \%$ difference in nerve fiber density between patients with and patients without pain [6]. Based on their findings, it was estimated that 12 patients would have to be included into each group to achieve a $69 \%$ difference between two groups with 0.05 alpha error and $95 \%$ power.

The visual analog scale (VAS) was used to measure pain levels before surgery. The VAS scale was administered to all patients by the same physician. Forty-eight patients were prospectively included in the study; 25 patients with leiomyoma without pelvic pain (VAS < 5) were assigned into Group 1, 23 patients with leiomyoma and pelvic pain (VAS $\geq 5$ ) were assigned into Group 2.

\section{Collection of tissue samples}

The tissue samples were obtained from the endometrium, myometrium and uterine leiomyoma. The number and density of myelinated and unmyelinated nerve fibers were investigated using Protein Gene Product 9.5 (PGP 9.5) and neurofilament (NF) staining ( $\triangleright$ Figs. 1 and 2 ). 


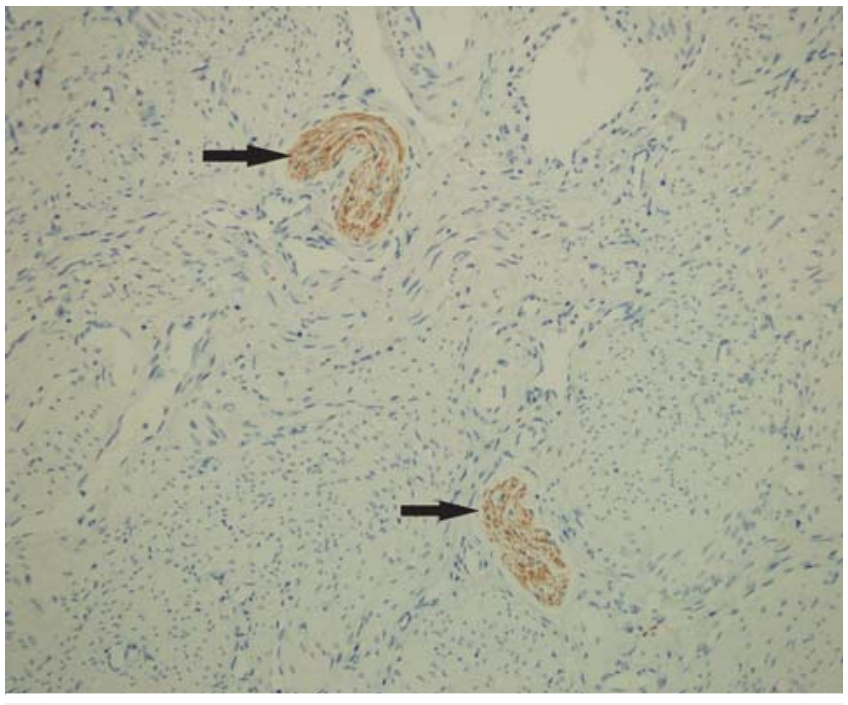

- Fig. 1 Nerve fibers in fibroid tissue (× 200, PGP 9.5). Tissue samples were obtained from uterine leiomyoma. The density and number of nerve fibers were investigated with Protein Gene Product 9.5 (PGP 9.5) staining.

\section{Histopathological examination}

Formalin-fixed paraffin-embedded tissue samples were incubated for 30 minutes with rabbit polyclonal Anti-PGP 9.5 (CELL MARQUE, Code CMC 31811021, 1/200 dilution, USA) or Anti-neurofilament (2F11) mouse monoclonal antibody (CELL MARQUE, Code CMC 30221021, 1/200 dilution, USA). Post-primary antibody, polymer antibody and diaminobenzidine (DAB) were added, respectively. Paraffin sections were stained using Mayer's hematoxylin. All samples were evaluated by the same pathologist using an Olympus BX53 microscope. The diagnosis of uterine leiomyoma was confirmed in all patients by histopathologic examination.

\section{Statistical analysis}

Data were analyzed using SPSS version 22.0. Mean standard deviation, median (lowest and highest), frequency and ratio values were used for descriptive statistics. Histogram, normality plots and Shapiro-Wilk normality test were used to analyze data distribution. Mann-Whitney $U$ test was used to analyze quantitative data. $x^{2}$ test or Fisher's exact test was used to analyze qualitative data. Cohen's kappa coefficient was used to measure agreement

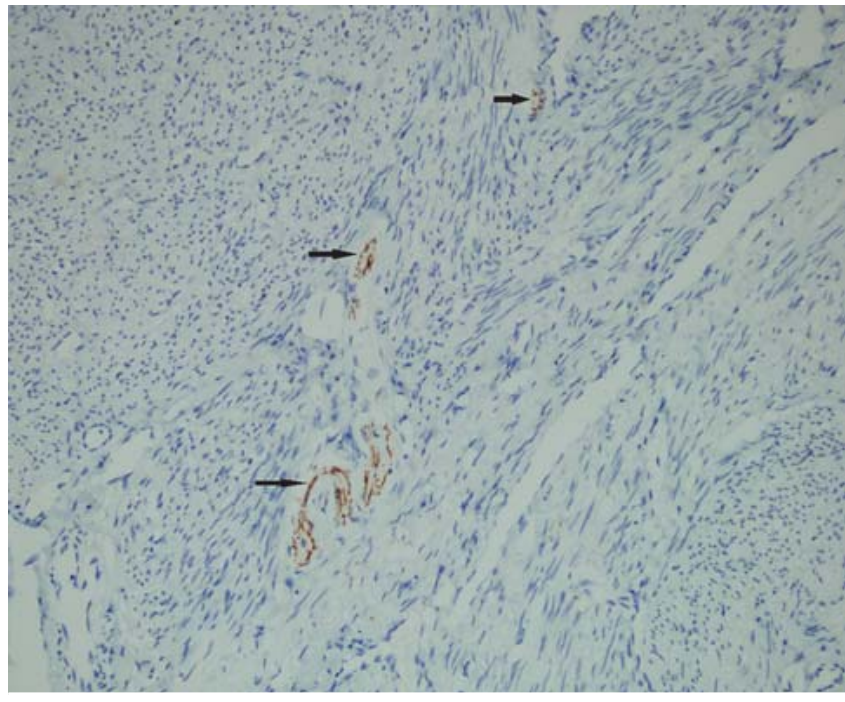

- Fig. 2 Nerve fibers in fibroid tissue $(\times 200$, NF). Tissue samples were obtained from uterine leiomyoma. The density and number of nerve fibers were investigated with neurofilament (NF) staining.

between the two staining techniques. Statistical significance was established at $\mathrm{p}<0.05$.

\section{Results}

\section{Demographic data}

There were no statistically significant differences between the two groups with regard to age, number of pregnancies, and size and location of uterine leiomyomas. There was a statistically significant difference between groups with regard to VAS pain scores and duration of pain $(p<0.05)(\bullet$ Table 1$)$.

\section{Endometrial samples}

None of the endometrial samples from either of the groups stained with PGP 9.5 or NF. The distance of nerve fibers to the endometrial lining was similar in both groups $(p>0.05)$.

- Table 1 Patient demographics.

\begin{tabular}{|l|l|l|l|}
\hline & Group $\mathbf{1}(\mathbf{n = 2 5 )}$ & Group 2 (n=23) & P \\
\hline Age (years) & $47 \pm 2.86$ & $46.21 \pm 3.27$ & 0.06 \\
\hline Gravida & $3(1-11)$ & $3(1-7)$ & 0.63 \\
\hline Size of uterine fibroid (cm) & $7.68 \pm 4.02$ & $8.91 \pm 4.99$ & 0.53 \\
\hline Duration of pain (months) & $2(0-24)$ & $12(2-72)$ & $<0.005$ \\
\hline VAS (visual analog scale) pain scores & $2(0-4)$ & $7(6-8)$ & $<0.005$ \\
\hline
\end{tabular}


- Table 2 Comparison of presence and density of nerve fibers between groups.

\begin{tabular}{|c|c|c|c|c|c|c|}
\hline & \multicolumn{2}{|l|}{ PGP 9.5} & \multirow[t]{2}{*}{ P } & \multicolumn{2}{|l|}{ NF } & \multirow[t]{2}{*}{ P } \\
\hline & $\begin{array}{l}\text { Group } 1 \\
(n=25)\end{array}$ & $\begin{array}{l}\text { Group } 2 \\
(n=23)\end{array}$ & & $\begin{array}{l}\text { Group } 1 \\
(n=25)\end{array}$ & $\begin{array}{l}\text { Group } 2 \\
(n=23)\end{array}$ & \\
\hline $\begin{array}{l}\text { Presence of nerve fibers } \\
\text { in endometrium }\end{array}$ & - & - & & - & - & \\
\hline $\begin{array}{l}\text { Presence of nerve fibers } \\
\text { in myometrial tissue (\%) }\end{array}$ & 84 & 70 & 0.23 & 88 & 74 & 0.28 \\
\hline $\begin{array}{l}\text { Density of nerve fibers in } \\
\text { myometrial tissue (per } \mathrm{mm}^{2)}\end{array}$ & $0.1 \pm 0.22$ & $0.1 \pm 0.21$ & 0.39 & $0.06 \pm 0.09$ & $0.07 \pm 0.12$ & 0.83 \\
\hline $\begin{array}{l}\text { Density of nerve fibers } \\
\text { in fibroid tissue (per } \mathrm{mm}^{2)}\end{array}$ & $0.001 \pm 0.006$ & $0.001 \pm 0.003$ & 0.29 & $0.004 \pm 0.013$ & $0.002 \pm 0.007$ & 0.65 \\
\hline $\begin{array}{l}\text { Percentage of nerve fibers } \\
\text { in uterine fibroid tissue (\%) }\end{array}$ & $4(n=1)$ & $13(n=3)$ & $>0.05$ & $12(n=3)$ & $9(n=2)$ & $>0.05$ \\
\hline
\end{tabular}

\section{Myometrial samples}

The percentage of nerve fibers stained with PGP 9.5 in myometrial tissue was $84 \%(n=21)$ in Group 1 and $70 \%(n=16)$ in Group 2 $(p=0.23)$. The percentage of nerve fibers stained with NF in myometrial tissue was $88 \%(n=22)$ in Group 1 and $74 \%(n=17)$ in Group $2(p=0.28)$. The density of nerve fibers stained with PGP 9.5 in myometrial tissue was $0.1 \pm 0.22$ per $\mathrm{mm}^{2}$ in Group 1 and $0.1 \pm 0.21$ per $\mathrm{mm}^{2}$ in Group $2(p=0.39)$. The density of nerve fibers stained with NF in myometrial tissue was $0.06 \pm 0.09$ per $\mathrm{mm}^{2}$ in Group 1 and $0.07 \pm 0.12$ per $\mathrm{mm}^{2}$ in Group $2(\mathrm{p}=0.83)$. There was no statistically significant difference between the two groups ( $\triangleright$ Table 2 ).

\section{Leiomyoma tissue samples}

The percentage of nerve fiber tissue stained with PGP 9.5 in uterine leiomyoma tissues was 4\% $(n=1)$ in Group 1 and $13 \%(n=3)$ in Group 2 ( $p>0.05)$. The percentage of nerve fiber tissue stained with NF in uterine leiomyoma tissues was $12 \%(n=3)$ in Group 1 and $9 \%(n=2)$ in Group $2(p>0.05)$. The density of nerve fibers stained with PGP 9.5 in uterine leiomyoma tissues was $0.001 \pm 0.06$ per $\mathrm{mm}^{2}$ in Group 1 and $0.001 \pm 0.003$ per $\mathrm{mm}^{2}$ in Group $2(p=0.29)$. The density of nerve fibers stained with NF in uterine leiomyoma tissues was $0.004 \pm 0.013$ per $\mathrm{mm}^{2}$ in Group 1 and $0.002 \pm 0.007$ per $\mathrm{mm}^{2}$ in Group $2(p=0.65)$. There was no statistically significant difference between the two groups ( $\triangleright$ Table 2).

When we look at the consistency between the two dyeing methods, nerve fibers in uterine leiomyoma tissues showed fair agreement $(p<0.05 / \mathrm{k}=0.388)$ and nerve fibers in myometrial tissues showed substantial agreement $(p<0.05 / k=0.622)$. The distribution of nerve fibers in myometrial and leiomyoma tissue was similar in both groups with both dyes.

\section{Discussion}

Physiologically, uterine innervation is regulated by estrogen and progesterone through neurotrophins (nerve growth factor, prostaglandins, etc.) $[9,10]$. In estrogen-dependent diseases such as endometriosis, adenomyosis and uterine leiomyoma, estrogen may play a role in the increase of nerve fibers in the endometrium and myometrium by regulating neurotrophins. It is known that there are no nerve fibers in the functional layer of the endometrium. In recent years, however, many publications have identified nerve fibers in endometrial specimens of endometriosis patients who present with pain complaints [5,6,11-13]. Based on these findings, we thought that investigating the presence of nerve fibers in uterine leiomyoma patients could shed light on the etiopathogenesis of leiomyoma-associated pain.

There is only one study on the innervation of endometrial and myometrial tissue in patients with painful uterine leiomyomas [7]. In this study, the density of PGP 9.5-stained nerve fibers was significantly higher in the functional and basal layer of the endometrium in patients with uterine leiomyoma and pain complaint. According to the authors, nerve fibers in the functional layer of the endometrium could play a role in the pathogenesis of pain in patients with endometriosis, adenomyosis and uterine leiomyomas with pain complaint. In contrast to their results, in our study nerve fibers could not be detected in endometrial tissue of any of the patients using PGP 9.5 and NF dye. The absence of nerve fibers in the endometrium may be due to endometrial compression atrophy associated with large uterine leiomyomas (mean size: $8.27 \pm 4.50 \mathrm{~cm}$ ) in our study group.

In recent years, several studies have indicated that the amount of nerve fibers in the myometrium of patients with pelvic pain is higher than in patients without pain [14-16]. Lerner and his coworkers reported on the proliferation and hypertrophy of unmyelinated nerve fibers in the myometrium of patients with chronic pelvic pain [13]. In another study, nerve fiber proliferation was detected in myometrial tissue around the arteries and veins of patients with endometriosis-associated dysmenorrhea and dyspareunia [15]. Sun et al. investigated increased nerve fiber density in pseudo-capsules using staining with anti-oxytocin and PGP 9.5 and compared the result to findings for the adjacent myometrium. However they did not compare the nerve fiber density of patients with and patients without pain [17]. Their findings indicate that pelvic pain could be correlated with increased myometrial 
nerve fibers. In our study, nerve fibers in the myometrium stained with PGP 9.5 and NF were detected in 77 and $81 \%$ of all patients, respectively. But there was no significant difference between patients with and patient without pain with regard to nerve fiber density in myometrial tissue detected by staining with PGP 9.5 $(p=0.39)$ and NF $(p=0.83)$.

In the literature the only study related to innervation in leiomyomas is a retrospective qualitative study which demonstrated that leiomyomas in multiparous women do not contain nerves while leiomyomas in nulliparous women contain nerves [18]. We investigated the density of nerve fibers in uterine leiomyoma tissue. Nerve fibers stained with PGP 9.5 and NF in leiomyoma tissue were detected in 8 and $10 \%$ of patients, respectively. We found that there was no significant difference between patients with and patients without pain in terms of nerve fiber density in uterine leiomyoma tissue based on staining with PGP $9.5(p=0.29)$ and NF $(p=0.65)$.

The diagnosis of uterine leiomyoma was confirmed in all patients by histopathologic examination. The strength of this study which investigated nerve fiber density in uterine leiomyoma tissue, endometrial and myometrial tissue was its prospective design and quantitative approach. To the best of our knowledge, the current study is the first quantitative study investigating nerve fiber density in uterine leiomyoma tissue. The relatively small sample size can be viewed as a limitation.

In conclusion, the mechanisms of dysmenorrhea and pelvic pain in patients with uterine leiomyoma are not yet fully understood. In our study, NF and PGP 9.5 immunoreactive-staining nerve fibers were not detected in the endometrium of any patients with uterine leiomyoma and pain complaint. The quantity and density of nerve fibers in myometrial and leiomyoma tissue in patients with pain was similar to that detected in patients without pain. A population-based study is needed to investigate the mechanism of pain in uterine leiomyomas.

\section{Conflict of Interest}

The authors declare that they have no conflict of interest.

\section{References}

[1] Marsh EE, Ekpo GE, Cardozo ER et al. Racial differences in fibroid prevalence and ultrasound findings in asymptomatic young women (18-30 years old): a pilot study. Fertil Steril 2013; 99: 1951-1957

[2] Lippman SA, Warner M, Samuels S et al. Uterine fibroids and gynecologic pain symptoms in a population-based study. Fertil Steril 2003; 80: 1488 1494

[3] Katz J, Melzack R. Measurement of pain. Surg Clin North Am 1999; 79: 231-252

[4] Medina MG, Lebovic DI. Endometriosis-associated nerve fibers and pain. Acta Obstet Gynecol Scand 2009; 88: 968-975

[5] Tokushige N, Markham R, Russell P et al. High density of small nerve fibres in the functional layer of the endometrium in women with endometriosis. Hum Reprod 2006; 21: 782-787

[6] Zhang $X$, Lu B, Huang $X$ et al. Endometrial nerve fibers in women with endometriosis, adenomyosis, and uterine fibroids. Fertil Steril 2009; 92: 1799-1801

[7] Zhang X, Lu B, Huang X et al. Innervation of endometrium and myometrium in women with painful adenomyosis and uterine fibroids. Fertil Steril 2010; 94: 730-737

[8] Tokushige N, Markham R, Russell P et al. Nerve fibres in peritoneal endometriosis. Hum Reprod 2006; 21: 3001-3007

[9] Bjorling D, Beckman M, Clayton M et al. Modulation of nerve growth factor in peripheral organs by estrogen and progesterone. Neuroscience 2002; 110: 155-167

[10] Krizsan-Agbas D, Pedchenko T, Hasan W et al. Oestrogen regulates sympathetic neurite outgrowth by modulating brain derived neurotrophic factor synthesis and release by the rodent uterus. Eur J Neurosci 2003; 18: $2760-2768$

[11] Meibody FA, Kashi AM, Mirzaie AZ et al. Diagnosis of endometrial nerve fibers in women with endometriosis. Arch Gynecol Obstet 2011; 284: 1157-1162

[12] Al-Jefout M, Dezarnaulds G, Cooper M et al. Diagnosis of endometriosis by detection of nerve fibres in an endometrial biopsy: a double blind study. Hum Reprod 2009; 24: 3019-3024

[13] Tokushige N, Markham R, Russell P et al. Different types of small nerve fibers in eutopic endometrium and myometrium in women with endometriosis. Fertil Steril 2007; 88: 795-803

[14] Atwal G, du Plessis D, Armstrong G et al. Uterine innervation after hysterectomy for chronic pelvic pain with, and without, endometriosis. Am J Obstet Gynecol 2005; 193: 1650-1655

[15] Quinn M, Armstrong G. Uterine nerve fibre proliferation in advanced endometriosis. J Obstet Gynaecol 2004; 24: 932-933

[16] Quinn M], Kirk N. Differences in uterine innervation at hysterectomy. Am J Obstet Gynecol 2002; 187: 1515-1520

[17] Sun Y, Zhu L, Huang $X$ et al. Immunohistochemical localization of nerve fibers in the pseudocapsule of fibroids. Eur J Histochem 2014; 58: 2249

[18] Quinn M. Uterine innervation in fibroids: a qualitative study. J Obstet Gynaecol 2007; 27: 489-492 